\title{
Investigating the effects of issuance of bank debt guarantee on profitability of banking industry
}

\author{
Reza Pirayesh $^{\mathrm{a}^{*}}$ and Majid Gharagozloo ${ }^{\mathrm{b}}$
}

${ }^{a}$ Assistant Professor, Department of Management and Accounting, University of Zanjan, Zanjan, Iran ${ }^{b}$ Masters of Business Administration

C H R O N I C L E

\begin{tabular}{l}
\hline Article history: \\
Received June 28, 2013 \\
Received in revised format \\
19 October 2013 \\
Accepted 20 December 2013 \\
Available online \\
December 292013 \\
\hline Keywords: \\
Bank debt guarantee \\
Customer retention \\
Profitability \\
Bank resources
\end{tabular}

\begin{abstract}
A B S T R A C T
This paper presents an empirical investigation to study the relationship between bank debt guarantee and profitability, increase in banks resources and customer retention. The proposed study has been implemented in one of Iranian banks located in city of Zanjan, Iran over the period of 10 years. The study has used Pearson correlation test to examine three hypotheses of the survey. The results indicate that there were positive and meaningful relationship between bank debt guarantee and profitability $(\mathrm{r}=0.863$, P-value $=0.001)$, a positive relationship between bank debt guarantee and bank resources $(r=0.708$ with $P$-value $=0.015)$ and there was a positive and meaningful relationship between bank debt guarantee and customer retention $(\mathrm{r}=0.252$ with $\mathrm{P}$-value $=0.001)$.
\end{abstract}

(c) 2014 Growing Science Ltd. All rights reserved.

\section{Introduction}

There are various activities associated with banking industry such as giving loans, financing projects, etc. (Schich \& Lindh, 2012). One of the most popular activities in this industry is associated with bank debt guarantees, it plays essential role on the success of most banking systems, and there are many studies associated with it. Arping (2010), for instance, analyzed the desirability of fair pricing of government guarantees for bank liabilities. Jacques et al. (2011) compared two strategies for replicating a put option implemented to synthetize a debt guarantee contract. The first strategy, superreplication, while keeping the portfolio value bigger or equal to a target value, minimized the transaction expenses of replicating a debt insurance put option by applying dynamic linear programming. The second strategy replicated this put option by maximizing the guarantor's expected utility. They reported that both strategies could give better results than the alternative method. If we apply a risk-adjusted performance metric, the utility-based method could also perform the best when transaction expenses were relatively low.

* Corresponding author. Tel: +98 2415152290

E-mail addresses: r_pirayesh@znu.ac.ir (R. Pirayesh) 
Mälkönen and Niinimäki (2012) investigated blanket guarantee, deposit insurance and restructuring decisions in terms of a multinational bank (MNB) using Nash bargaining when the threat of a bank panic motivates countries to make decisions quickly. Failure of the bank would unevenly distributed externalities across various countries, impacting the restructuring incentives. In equilibrium, the bank was either liquidated or one of the countries - or both - recapitalizes it. A partition of the recapitalization expenses was sensitive to the country-specific advantages and expenses from recapitalization, panic and liquidation. The home regulator could benefit from the advantage that it could be the only entity, which could legally liquidate the MNB. Nguyen (2013) investigate the disciplinary impact of subordinated debt on bank risk taking in the period 2002-2008 based on data for publicly listed commercial banks and bank holding companies around the world. The study also examined whether or not the effects depend on national bank regulations, legal and institutional conditions. The results recommended a threshold level of national bank regulations and economic development above which subordinated debt mitigates risk taking. The evidence supported the efficacy of proposals calling for increased implementation of subordinated debt in banking firms.

Ono et al. (2013) investigated the effectiveness of Japan's Emergency Credit Guarantee (ECG) Program set up in the events of the financial turmoil following the failure of Lehman Brothers, in increasing credit availability and improving the ex-post performance of small businesses. More specifically, using a unique firm-bank matched dataset, they examined whether lending relationships enhanced or dampened the impacts of the ECG program and reported that the ECG program significantly could improve credit availability for firms applying the program. However, when it was a relationship lender that extended an ECG loan, the increased availability was partially, if not completely, offset by a decrease in non-ECG loans by the same bank. In addition, propensity score matching estimations demonstrated that the ex-post performance of firms that had received ECG loans from the main bank deteriorated more than that of firms that received non-ECG loans.

Schneider and Tornell (2004) provided a framework of boom-bust episodes in middle-income countries based on sectoral differences in corporate finance where the nontradables sector was special because it encountered a contract enforceability problem and enjoys bailout guarantees. Therefore, currency mismatch and borrowing constraints arose endogenously in that sector. This sectoral asymmetry permitted the model to replicate the main features of observed boom-bust episodes. More specifically, episodes begin with a lending boom and a real appreciation, peak in a self-fulfilling crisis during which a real depreciation coincides with widespread bankruptcies, and end in a recession and credit crunch.

According to Bakhtiari et al. (2013), affinity card programs have become very popular in recent years and account for one fifth of all credit card accounts. There are some evidences to believe that these loan programs may influence profitability, significantly.

\section{The proposed model}

This paper presents an empirical investigation to study the relationship between bank debt guarantee and profitability, increase in banks resources and customer retention (Wu, 2012). The proposed study has been implemented in one of Iranian banks located in city of Zanjan, Iran over the period of 10 years.

The proposed study of this paper considers the following three hypotheses,

1. There is a meaningful relationship between issuance of bank debt guarantee and profitability in banking industry.

2. There is a meaningful relationship between issuance of bank debt guarantee and increase in banks' financial resources. 
3. There is a meaningful relationship between issuance of bank debt guarantee and customer retention as well as absorbing new customers.

The proposed study has been implemented in one of Iranian banks named Tejarat in city of Zanjan, Iran. The study gathers the necessary information on the amount of deposits, issued bank debt guarantees and the amount of commissions received over the period 2001-2011. Table 1 demonstrates the results of some basic statistics associated with three gathered figures.

\section{Table 1}

The summary of some basic statistics (Million Rials)

\begin{tabular}{cccc}
\hline Item & Bank debt guarantee & Deposit & Commission \\
\hline Number & 11 & 11 & 11 \\
Error & 0 & 0 & 0 \\
Mean & 757073.0603 & 73370.0615 & 18223.5466 \\
Std. Dev. & 3.062355 & 31069.18435 & 5609.75950 \\
Median & 279500.0000 & 9784.0000 & 12779.2500 \\
Mode & 26428.00 & 2642.00 & 869.85 \\
Variance & 1.03212 & 1.06210 & 3.4628 \\
\hline Rage & 2941915.00 & 294192.00 & 43655.15 \\
Min & 26428.00 & 2642.00 & 869.85 \\
\hline Max & 2968343.00 & 296834.00 & 44525.00 \\
\hline
\end{tabular}

As we can observe from the results of Table 1, bank debt guarantee maintain an average of 757073 million Rials with standard deviation of 3 million Rials. Deposit is another variable, which maintains a mean of 73370 million Rials and standard deviation of 31069 million Rials. Finally, commission is the last item with the mean of 18223 million Rials and standard deviation of 5610 million Rials. We have realized that all data were normally distributed through the implementation of KolmogorovSmirnov. Therefore, the proposed study uses Pearson correlation test to verify different hypotheses of the survey.

\section{The results}

In this section, we present details of our findings on testing various hypotheses of the survey.

\subsection{The relationship between bank debt guarantee and profitability}

The first hypothesis of the survey is associated with the relationship between bank debt guarantee and profitability in banking sector. The implementation of Pearson correlation test between these two components yields $r=0.863$ with $\mathrm{P}$-value $=0.001$, which means there was a positive and meaningful relationship between these two components when the level of significance is five percent and we can confirm the first hypothesis of the survey.

\subsection{The relationship between bank debt guarantee and increase in bank resources}

The second hypothesis of the survey is associated with the relationship between bank debt guarantee and increase in bank resources. The implementation of Pearson correlation test between these two components yields $r=0.708$ with $\mathrm{P}$-value $=0.015$, which means there was a positive and meaningful relationship between these two components when the level of significance is five percent and we can confirm the second hypothesis of the survey. 
3.3. The relationship between bank debt guarantee and customer retention as well as new customer absorption

The third hypothesis of the survey is associated with the relationship between bank debt guarantee and customer retention as well as new customer absorption in banking sector. The implementation of Pearson correlation test between these two components yields $r=0.252$ with $P$-value $=0.001$, which means there was a positive and meaningful relationship between these two components when the level of significance is five percent and we can confirm the third hypothesis of the survey.

\section{Conclusion}

In this paper, we have presented an empirical investigation to study the relationship between bank debt guarantee and profitability, increase in banks resources and customer retention. The proposed study has been implemented in one of Iranian banks located in city of Zanjan, Iran over the period of 10 years. The study has used Pearson correlation test to examine three hypotheses of the survey. The results indicate that there were positive and meaningful relationship between bank debt guarantee and profitability $(\mathrm{r}=0.863$, P-value $=0.001)$, a positive relationship between bank debt guarantee and bank resources $(r=0.708$ with P-value $=0.015)$ and there was a positive and meaningful relationship between bank debt guarantee and customer retention $(r=0.252$ with $\mathrm{P}$-value $=0.001)$. Therefore, it is essential to expand the operations of bank debt guarantee.

\section{Acknowledgement}

The authors would like to thank the anonymous referees for constructive comments on earlier version of this paper.

\section{References}

Arping, S. (2010). The pricing of bank debt guarantees. Economics Letters, 108(2), 119-121.

Bakhtiari, A., Murthi, B.P.S., \& Steffes, E. (2013). Evaluating the Effect of Affinity Card Programs on Customer Profitability Using Propensity Score Matching. Journal of Interactive Marketing, 27(2), 83-97

Jacques, S., Lai, V.S., \& Soumaré, I. (2011). Synthetizing a debt guarantee: Super-replication versus utility approach. International Review of Financial Analysis, 20(1), 27-40.

Mälkönen, V., \& Niinimäki, J.-P. (2012). Blanket guarantee, deposit insurance and restructuring decisions for multinational banks. Journal of Financial Stability, 8(2), 84-95.

Nguyen, T. (2013). The disciplinary effect of subordinated debt on bank risk taking. Journal of Empirical Finance, 23, 117-141.

Ono, A., Uesugi, I., Yasuda, Y. (2013). Are lending relationships beneficial or harmful for public credit guarantees? Evidence from Japan's emergency credit guarantee program. Journal of Financial Stability, 9(2), 151-167.

Schneider, M., \& Tornell, A. (2004). Balance sheet effects, bailout guarantees and financial crises. The Review of Economic Studies, 71(3), 883-913.

Schich, S., \& Lindh, S. (2012). Implicit guarantees for bank debt: Where do we stand?. OECD Journal-Financial Market Trends, 102, 45.

Wu, H.Y. (2012). Constructing a strategy map for banking institutions with key performance indicators of the balanced scorecard. Evaluation and Program Planning, 35(3), 303-320 